http://dx.doi.org/10.5935/1981-2965.20130015.

Artigo Cientifico

http://www.higieneanimal.ufc.br

\title{
Seropositivity to Leptospira interrogans Canicola local isolate associated to tongue necrosis in dog without significant hematological alterations
}

Soropositividade para um isolado local de Leptospira interrogans Canicola associado à necrose de lingua em cão sem a presença de alterações hematológicas

\section{Sérgio Jorge ${ }^{1}$; Monte, Leonardo Garcia Monte ${ }^{1}$; Natasha Rodrigues Oliveira ${ }^{1}$; Odir Antonio Dellagostin ${ }^{1}$; Claudiomar Soares Brod, ${ }^{2}$; Cláudia Pinho Hartleben ${ }^{1}$}

${ }^{1}$ Núcleo de Biotecnologia, Centro de Desenvolvimento Tecnológico, Universidade Federal de Pelotas (CDTec/UFPel): Sérgio Jorge, sergiojorgevet@ hotmail.com; Leonardo Garcia Monte, leonardogmonte@hotmail.com; Natasha Rodrigues Oliveira, oliveira_natasha@ hotmail.com;

Odir Antonio Dellagostin, odir@terra.com.br; Cláudia Pinho Hartleben, clauhart@terra.com.br;

${ }^{2}$ Centro de Controle de Zoonoses, Faculdade de Veterinária, UFPel: Claudiomar Soares Brod, claudiomarbrod@yahoo.com.br.

*Author correspondence address: Sérgio Jorge, Núcleo de Biotecnologia, Centro de

Desenvolvimento Tecnológico, Universidade Federal de Pelotas, Campus Capão do Leão, Email address: sergiojorgevet@hotmail.com

Abstract: Leptospirosis is a global zoonosis caused by infection with the spriochetal bacterium of the genus, Leptospira. Dogs may be exposed to leptospires in the environment by contact with urine of an infected host, contaminated water or moist soil, where the bacteria may survive for several months. In this work, we report the clinical case of a dog suffering tip of the tongue necrosis caused by pahogenic L. interrogans serovar Canicola strain Tande. Laboratorial examinations demonstrated urinalysis and blood chemistry changes without significant hematological alterations. The 3.200 antibodies titers against Tande strain were detected on Microscopic Agglutination Test (MAT), confirming the diagnosis of leptopirosis. Aggressive fluid therapy and $\beta$-lactâmic antibiotics were used for treatment and to prevent and treat acute kidney damage. The dog had a complete clinical recovery after treatment.

Keywords: leptospirosis, serology, local isolate 
Resumo: A leptospirose é uma zoonose de distribuição mundial causa por bactérias espiroquetas do gênero Leptospira spp. Cães são expostos ao agente por meio de urina de hospedeiros infectados, água ou solo contaminados, onde bactéria pode sobreviver por muitos meses. Neste trabalho, relatamos o caso clínico de um cão apresentando como sinal clínico necrose da ponta da língua associada a uma infeção aguda pela patogênica $L$. iterrogans Canicola cepa Tande. A infecção aguda por esta cepa patogênica causou mudança nos parâmetros da bioquímica sérica e na urinálise, sem causar alterações hematológicas. Título de anticorpos de 3.200 contra cepa Tande foram detectados pelo teste de soroaglutinação microscópica (MAT), confirmando o diagnóstico de leptospirose. A associação de antibióticos $\beta$-lactâmicos foram utilizados para combater a infecção aguda e fluidoterapia agressiva foi adotada para previnir insuficiência renal. O cão obteve recuperação clínica após tratamento.

Palavras-chave: leptospirose, sorologia, isolado local

\footnotetext{
*Author correspondence address: E-mail address: sergiojorgevet@ hotmail.com Recebido em 10.03.2013. Aceito 20.07.2013
}

\section{Introduction}

Canine leptospirosis is caused by infection by pathogenic bacteria of genus Leptospira which is classified into 12 pathogenic species and with antigenically distinct serovars (LEVETT, 2001). The infection in dogs known as Stuttgard disease, is a zoonotic emerging bacterial disease (ALTON et al., 2006; RENTKO et al., 1992; LEVETT, 2001). The bacteria gains access to new hosts by passage through mucous membranes or skin abrasions, often from environmental sources, such as urine-contaminated water 
(FAINE et al., 1999; LEVETT, 2001). The development of the canine leptospirosis depends on age and immunity of the host, environmental factors and virulence of the infecting serovar that is heterogeneous throughout the world (FAINE et al., 1999).

Isolation followed by typing from renal carriers is important and very useful in epidemiological studies to determine which serovars are present within a particular group of animals, animal species, or a geographical region (FAINE et al., 1999). Leptospira interrogans serovar Canicola strain Tande was isolated in Southern Brazil from urine samples from a dog with clinical signs, hematological, blood chemistry and urinary changes typical in canine leptospirosis. The Tande strain increased 20 per cent of enhanced MAT sensitivity when it was included in this serologic diagnosis using dog sera samples in the same study area (BROD et al., 2005). In this work, we report a clinical case of canine leptospirosis in an animal suffering from the tip of the tongue necrosis and had urinalysis test and blood chemistry changes caused by acute infection by $L$. interrogans Canicola Tande strain without significant hematological alterations.

A three years old poodle dog, male, weighing $3.8 \mathrm{~kg}$, unvaccinated against leptospirosis was brought to the Veterinary Hospital of Federal University of Pelotas Brazil, where the owner referred to lethargy, emesis, dehydration, anorexia and foul odor in the mouth perceived approximately 4 days earlier. That animal lived near synanthropic rodents. Clinical examination revealed shrunken eyeballs, yellowish discoloration of the mucous membrane of conjunctiva, rectal temperature of $37.2{ }^{\circ} \mathrm{C}$ and tip tongue necrosis (Figure 1). 


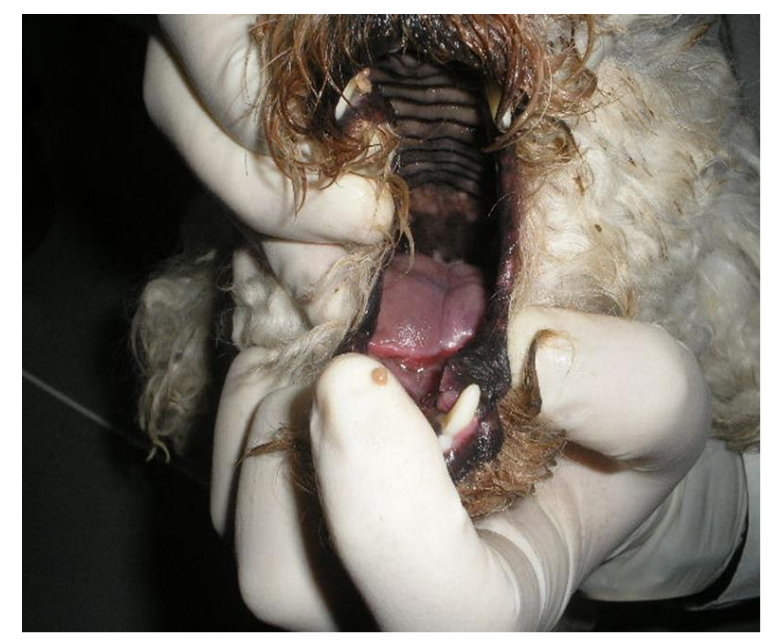

Figure 1. Tip tongue necrosis in dog associated with infection L. interrogans Canicola Tande strain.

Blood was collected by cephalic vein puncture with anti-coagulant for a hematological examination and without anticoagulant for biochemical and serological examinations: Complete blood count (CBC), and serum biochemistry: Alanine aminotransferase (ALT), Alkaline phosphatase (ALP), Creatinine and blood urea nitrogen (BUN), a Microscopic Agglutination Test (MAT) were performed to detect antibodies against Leptospira spp. using serovars recommended by the World Health Organization (TERPSTRA, 2003) plus canine local isolate (Tande strain). Sera were tested at dilutions of 1:100,
$1: 200, \quad 1: 400, \quad 1: 800, \quad 1: 1600, \quad 1: 3200$, $1: 6400,1: 12,800$. A urine sample was collected by catheterization for urinalysis test.

We detected in MAT antibodies titers of 100 against the both serovars Autralis and Bataviae, titers of 800 against the serovar Icterohaemorrhagiae, titer of 1.600 against the serovar Canicola, Hond Utrecht IV strain and titer of 3.200 against serovar Canicola, Tande strain (Table 1). Urinalysis was characterized by proteinuria, pyuria, and bilirubinuria and by increased numbers of granular casts, leukocytes, and hematuria (Table 1). 
Table 1 - Microscopic Agglutination Test (MAT) and Urinalysis results

\section{Microscopic Agglutination Test (MAT)}

\begin{tabular}{llllr} 
Species & Serogroup & Serovar & Strain & Titers \\
\hline L. interrogans & Australis & Australis & Ballico & 100 \\
& Bataviae & Bataviae & Swart & 100 \\
Bataviae & Bataviae & Van Tienem & 100 \\
Icterohaemorrhagiae & Icterohaemorrhagiae & RGA & 800 \\
Canicola & Canicola & Hond Utrecht IV & 1.600 \\
& Canicola & Canicola & Tande & 3.200
\end{tabular}

\section{Urinalisys}

Test

Physical examination

Urine color

Urine appearence

Specific gravity

Chemical examination

$\mathrm{Ph}$

Protein

Bilirubin

Microscopic examination

Squamous epithelial

Pus cells

Red blood cells

Bacteria

Cast granular
$<2$

\section{Result}

Amber

Cloudy

1041

6.0

$(+)$

$(++)$

30/HPF

1/HPF

Moderate

2/HPF

\section{Reference Value}

Straw to amber

Clear

1025-1040

6.0-7.0 (Acidic)

Negative

Negative

Few

0-5/HPF

0-2/HPF

Few

None 
In the hematological findings, WBC count and WBC differential count (neutrophils and lymphocytes), showed no exceess reference values (Table 2). In relation to biochemical findings, ALT, urea and creatinine exceeded reference values (Table 2). The dog had anacellular urinary sediment, which indicates the kidneys as the source of urine protein.

Canine leptospirosis caused primarily by L. interrogans and L. kirschneri has been associated with serovars Canicola, Icterohemorrhagiae, Grippotyphosa, Pomona and Bratislava (SYKES et al., 2011). Based on studies that focused on urban populations of dogs, serovars Canicola and Icterohemorrhagiae were considered the most prevalent serovars infecting dogs (FAINE, 1999), however, distinct pathogenic species and serovars had been isolated from dogs worldwide; in southern Brazil L. noguchii (SILVA et al., 2009) and L. interrogans Canicola, Tande strain (BROD et al., 2005) were isolated from dogs. Criteria for the canine diagnosis of leptospirosis consisted of clinical findings associated with one or more of the following criteria: A single serum MAT titer of greater than or equal to 1600 to a nonvaccinal serogroup in combination with a titer of 800 to serogroups Canicola and Icterohaemorrhagiae or a titer of greater than or equal to 1600 to serogroups Canicola and Icterohaemorrhagiae in a dog that never had been vaccinated against leptospirosis (GREENE, 2006), moreover, dogs with positive titers on MAT generally have sera that cross-react to a variety of serovars (MILLER et al., 2007; ANDREFONTAINE, 2006). In the clinical case reported here, we detected titer of 3.200 against serovar Canicola Tande strain and cross-react to others serovars (titer of 100 against serovars Australis and Bataviae, 800 against serovar Icterohaemorrhagiae and 1.600 against serovar Canicola Hond Utrecht IV) that, associated with the 
epidemiological data, changes in urinalisys test, serum biochemistry and clinical signs, confirming the diagnosis of acute leptospirosis.

Leukocyte counts fluctuate depending on the stage and severity of leptospirosis infection and cannot show changes such as the clinical case reported here (Table 2). Clinical signs depend on the stage of disease; e.g.: acute infection generally including fever, shivering, muscle tenderness, vomiting, dehydration, peripheral vascular colapse, tachypea, rapid irregular pulse, poor capillary perfusion, hematemesis, hematochezia, melena, espistaxis, widespread petechiae, and Icterus (GREENE, 2006). The extent of damage to organs varies seems to depend on the virulence of the serovar, the inoculums, and host susceptibility (GOLDSTEIN, 2010). In this clinical case, the initial replication mainly damaged the endothelial cells causing the unusual clinical finding of the tip tongue necrosis and alterations in blood chemistry and urinalisys, caused by acute infection from local isolate from L. interrogans Canicola local isolate; the Tande strain was previously isolated from urine from a convalescent dog in the same study area suffering hepatic dysfunction, renal failure and a high titers detected in MAT (BROD et al., 2005), indicating that L. interrogans Canicola Tande strain is virulent for dogs, causing this unusual clinical tip of the tongue necrosis sign in both cases reported.

Treatment of leptospirosis involves supportive care and depends on the severity of the infection and the presence of renal or hepatic dysfunction and other complicating factors. Aggressive fluid therapy concurrent to the use of antibiotics is crucial to prevent and treat acute kidney damage. The extent of renal damage after treatment may play a key role in determining the long-term prognosis for affected dogs. 
Table 2. Values and reference ranges of the hematologic and biochemical blood results.

\section{Complete Blood Count (CBC)}

Reference Interval

Results

White blood cells (WBC)

$(\%)$

$\left(\mathrm{mm}^{3}\right)$

(\%) $\left(\mathrm{mm}^{3}\right)$

Basophils

$0-2$

$0-250$

$0 \quad 0$

Eosinophils

$$
5-12
$$

$500-1560$

$1 \quad 115$

Monocytes

$3-7$

$300-910$

$5 \quad 575$

Lymphocytes

$10-22$

$1035-2860$

$21 \quad 2415$

Banded neutrophils

$0-3$

$0-390$

$0 \quad 0$

Segmented neutrophils

$60-75$

$6000-9750$

$73 \quad 8395$

Total leukocytes count

$10000-13000$

11500

Red blood cells (RBC)

Erythrocytes

$6-8$ million $/ \mathrm{mm}^{3}$

7,0

Hemoglobin

$14-18 \mathrm{~g} \%$

16,3

Hematocrit

$42-55 \%$

49,0

Plasma total protein

$6-8 \mathrm{~g} \%$

9,1

\section{Blood Chemistry}

Tests

Blood urea nitrogen

Creatinine

Alanine Aminotransferase

Alcaline Phosphatase
(ALT)

(ALP)
Reference Interval

Results

(BUN)

15 a $30 \mathrm{mg} / \mathrm{dl}$

299,0 mg/dl

0,5 a $1,5 \mathrm{mg} / \mathrm{dl}$

$1,8 \mathrm{mg} / \mathrm{dl}$

5,3 a 19,8 UI

71,0 UI

8,5 a 60,6 UI

30,0 UI 
Antimicrobial therapy should be started as soon as the disease is suspected and usually reduce fever and bacteremia within a few hours after administration. The first goal for terminating bacteremia and sterilizing the urine can be a penicillin derivative (GOLDSTEIN, 2010). The prognosis of leptospirosis in dogs is fair to poor, depending on the clinical state of the patient at initial presentation and on the causative leptospiral serovar. Survival rates of $80 \%$ for dogs with acute renal failure due to leptospirosis have been reported (ADIN et al., 2000). In this clinical case, the prognosis was guarded, but recovery was possible. Hospitalization was necessary for aggressive fluid therapy and the use of broad spectrum antibiotics (AmpicilinStreptomycin). The dog was cured and had a complete clinical recovery after treatment.

\section{References}

ADIN, C.A.; COWGILL, L.D. Treatment and outcome of dogs with leptospirosis: 36 cases (1990-1998). Journal of American Veterinary Medical Association, v.216, p.371-375, 2000.

ALTON, G.D.; BERKE， O.; REIDSMITH, R.; OJKIC, D.; PRESCOTT, J.F. Increase in seroprevalence of canine leptospirosis and its risk factors, Ontario 1998-2006. Canadian Jounal of Veterinary Research, v.73, n.3, p.167175, 2009.

ANDRE-FONTAINE G. Canine leptospirosis - do we have a problem? Veterinary Microbiology, v.117, n.1, p.1924, 2006.

BROD, C.S.; ALEIXO, J.A.G.; JOUGLARD, S.D.D.; FERNANDES, C.P.H.; TEIXEIRA, J.L.R.; DELLAGOSTIN, O.A. Evidência do cão como reservatório da leptospirose humana: isolamento de um sorovar, caracterização molecular e utilização em inquérito sorológico. Revista da Sociedade Brasileira de Medicina Tropical, v.38, n.4, p.294-300, 2005.

FAINE, A.B.; BOLIN, P. Leptospira and leptospirosis, 2th ed. Melbourne: MedSci, 1999. 353p. 
GOLDSTEIN, R.E. Canine Leptospirosis. Veterinary Clinics of North America: Small Animal Practice, v. 40, n.6, p.1091-1101, 2010.

GREENE, C.E.; SYKES, J.E; MOORE, G.E.; GOLDSTEIN, R.E.; SCHLTZ, R.D. Leptospirosis. In: GREENE, C. E. Infectious Diseases of the Dog and Cat. 3th ed, St. Louis Saunders Elsevier, 2006. cap.37, p. 431-446.

LEVETT, P.N. Leptospirosis. Clinical Microbiology Reviews, v.14, n.2, p.296326, 2001.

MILLER, R.I.; ROSS, S.P.; SULLIVAN, N.D.; PERKINS, N.R. Clinical and epidemiological features of canine leptospirosis in North Queensland. Australian Veterinary Journal, v.85, n.4, p. 13-19, 2007.

RENTKO, V.T.; CLARK, N.; ROSS, L.A.; SCHELLING, S.H. Canine leptospirosis. A retrospective study of 17 cases. Journal of Veterinay Internal Medicine, v.6:, p.235-244, 1992.

SILVA, E.F.; CERQUEIRA, G.M.; SEYFFERT, N.; SEIXAS, F.K.; HARTWIG, D.D.; ATANAZIO, D.A.; PINTO, L.S.; QUEIROZ, A.; KO, A.I.; BROD, C.S.; DELLAGOSTIN, O.A. Leptospira noguchii and human and animal leptospirosis, Southern Brazil. Emerging Infectious Disease, v.15, n.4, p.621-623, 2009.

TERPSTRA, W.J. Human Leptospirosis: Guidance for diagnosis, surveillance and control. Malta: World Health Organization, International Leptospirosis Society, 2003. 109p. 
Jorge et al., Revista Brasileira de Higiene e Sanidade Animal (v.7, n.2) p. 157 - 166 (2013) 